\title{
The Acceptance of Political Geography in Japan: A Citation Analysis of the 'International' Journal
}

\author{
YAMAZAKI Takashi* and KUMAGAI Mika** \\ Department of Geography, Osaka City University; Osaka 558-8585, Japan. \\ E-mail: yamataka@lit.osaka-cu.ac.jp*, kumaga02@lit.osaka-cu.ac.jp** \\ Received April 13, 2009; Accepted July 3, 2009
}

\begin{abstract}
This paper examines how the journal Political Geography has been accepted in Japan. Compared with other 'international' geographical journals widely subscribed to in Japan, the status of the journal is not necessarily high. However, following a general rise of political geographic studies in Japan, Japanese universities' subscription to the journal increased in number from the late 1980s to the early 1990s. The citation of the journal in major Japanese geographical journals has also been increasing. While the journal is accepted in such a way in Japan, the way Japanese geographers have cited articles in the journal points to some problematic aspects. Using the case of Japan, this paper illustrates how the 'international' journal is used outside the Anglophone world, assesses the role of the journal in the revitalization of political geography in Japan, and proposes some options to make the journal more international.
\end{abstract}

Key words Political Geography, subscription, citation, international journal, Japan

\section{Introduction ${ }^{1}$}

Political geography as a sub-discipline in human geography has not attracted many geographers in Japan since the end of the Second World War. Many Japanese geographers have ascribed the 'underdevelopment' of the sub-discipline to the legacy of Japanese geopolitics (e.g. Yamazaki 1995). However, as Yamazaki (1997) has shown with quantitative data, the increase of political geographic studies from the late 1950s to 60s does not support this reasoning. During this period Japanese political geography was still active as seen in the activities of the Japanese Association of Political Geographers (Nihon seiji chiri gakkai). It was during the following two decades (the 1970s-80s) that the sub-discipline became stagnant. Unlike Anglophone countries in which the revitalization of political geography was driven by growing interests in social and political issues such as the Vietnam War, urban riots, and other social problems in the 1960s and 70s (Taylor 2000a: 596), Japanese human geography seems to have de-politicized itself in such a politicized era.

Japanese radical (Marxist) geographers, however, began to criticize this de-politicized research trend in the 1970s (Takeuchi 1974, Mizuoka 1974). For them, the theoretical and disciplinary history of geography proved that geography itself contained 'the political' which could contribute to the expansion of state power. Therefore, they argued that even modern geography was not free from such a legacy of geopolitics. There was also an argument that in order to understand political meanings of being involved in governmental policy-making, it became necessary to construct a political geography with a perspective critical of governmental policies (Takeuchi 1986). These leftist critiques of the discipline, however, did not significantly affect the trend of Japanese geography at that time.

As Yamazaki (2001b) argues, the significant breakthrough of this de-politicized trend appeared in the 1990s. Since the end of the 20th century, academic interests in 'the political' have increased not only in geography but also in the human and social sciences as a whole and not only in developed countries including Japan but also in the whole world. What has stimulated interest in 'the political' are new academic trends such as postmodernism, post-structuralism, post-colonialism, and deconstruction. These trends represent radical critiques of the existing epistemological modes as a philosophical reflection on modernity in the late modern era. Responding to these trends, Japanese geographical studies are paying more attention to 'the political.' Such new trends are now spreading over sub-disciplines such as social, cultural, and political geographies. There seem to be two reasons for this perspective shift: one is the contextual or external reason that the paradigm of the 
nation-state has been severely questioned along with the (partial) end of the Cold War and globalization; ${ }^{2}$ the other is the theoretical or internal one that critical social theories have been actively introduced to Japanese human geography in order to overcome the epistemological limits of logical positivism and conventional Marxism. ${ }^{3}$ In sum, in parallel with recent changes in the human and social sciences in the world, human geography in Japan is experiencing a 'political turn' as a perceptible shift in its interest towards the political. ${ }^{4}$

In this context of the 'political turn,' we explore how the journal Political Geography (formerly Political Geography Quarterly, hereafter $P G$ ) has been accepted in Japan in order to assess the role of an English journal as a source of Anglo-American academic influence. As Sakamoto and Hamatani (1985) illustrate, postwar Anglo-American geography has significantly influenced the development of the Japanese counterpart. This influence, we argue, can be traced through the kinds of journals Japanese geographers have subscribed to and cited. As shown below, the fact that many Japanese university libraries are subscribing to Anglo-American geographical journals suggests how Anglo-American geographies have influenced Japanese geographers. We extend this assumption to our analysis. That is, when political geography has been revitalized in Japan, how has $P G$ been used and what kind of role has it played in Japan as a leading English journal in the sub-discipline? We attempt to answer these research questions.

\section{The Journal, Data, and Methodologies}

$P G$ was founded in 1982 and has been a representative journal in the sub-discipline of Anglophone countries. Currently eight issues are published per year, and each issue contains eight to fifteen articles including book reviews. The impact factor for $P G$ was 2.250 in 2003, which was the 4 th highest rating of all geography journals at that time (Elsevier 2005). There were over 69,000 full text downloads through the Internet during 2004 (ibid.).

Given that $P G$ is an international journal that has been frequently cited and has contributed to the theoretical and empirical development of political geography, we assume that $P G$ must have some impact on the politicization of Japanese human geography as well. If so, we could assess the nature of the impact by analyzing the subscription to and citation of the journal in Japan. By examining these aspects of the journal, we could also clarify whether the journal has actually contributed to the 'internationalization' of political geography outside the
Anglophone world, such as in Japan.

In order to investigate the above-mentioned aspects of the journal, we employed the following three methods. First, we conducted a survey on the increase (decrease) of political geographic studies from 1982 to 2004. Geographical Bibliography (Chirigaku bunken mokuroku) edited by the Human Geographical Society of Japan (Jinbun chiri gakkai) was used for this analysis. Geographical Bibliography Vol. 11 (Jinbun chiri gakkai bunken mokuroku henshu iinkai 2004) contains a CDROM database for the geographical books and articles published from 1987-2001. For the years from 19821986, we referred to Geographical Bibliography Vol. 8 (Jinbun chiri gakkai bunken mokuroku henshu iinkai 1989). The number of books and articles classified into "politics (seiji)" (labeled "politics" as the first or second subject) from 1982-2001 amounted to $353,{ }^{5} 37$ of which were refereed articles in the following major geographical journals in Japan: Annals of the Japan Association of Economic Geography (Keizai chirigaku nenpo), Geographical Review of Japan (Chirigaku hyoron), Geography Sciences (Chiri kagaku), the Japanese Journal of Human Geography (Jinbun chiri), and Quarterly Journal of Geography (Kikan chirigaku).

Second, a survey for the Japanese institutions possessing the journal was conducted. Using the National Institute of Informatics' NACSIS Webcat (NII 2005), which is the online union catalog database of academic documents in the collections of institutions such as university libraries and geography departments, we identified 33 institutions that subscribed to or possessed printed copies of the journal in 2005. We called or sent a fax to these institutions to ask the beginning and/or end of the subscription, the duration of the subscription, and other related questions. We also used the online database of each institution's library (OPAC) to specify the volumes and numbers of the journal it possessed.

Finally, we further collected the information about the citation of $P G$ using the above-mentioned five geographical journals. All the journals are edited by academic societies and have a peer referee system. Since they are regarded as representative journals of Japanese human geography, we believed that they would well reflect the contemporary trends of political geographic research in Japan. ${ }^{6}$ Based on the reference lists or footnotes of the articles (other than symposium summaries and book reviews) of each journal published from 1982-2004, we extracted the articles citing $P G$. The number of such articles amounted to 46 . They include three English articles, two of which were written by non- 
Japanese guest authors (Powell 1999, Smith 2000). The special issues and individual articles of $P G$ were cited 106 times. The number of the cited issues and articles was 78 . We reorganized these citation data by (co-)author so that we could examine which author(s) was/were frequently cited in Japan. The number of the (co-)authors cited by Japanese articles amounted to 54 . Using these data, we conducted citation analysis in order to assess $P G$ 's theoretical and empirical impacts on Japanese human geography.

\section{The Increase of Political Geographic Studies and Subscription to the Journal}

Figure 1 shows that the 'political turn' as mentioned in the Introduction can be identified as a general increase of political geographic studies in Japan. Books and articles classified into "politics" reached 35 in 1999 which is a year after the trend of subscription reached its peak. The citation to $P G$ appears to follow these trends. Figure 1 indicates that there are correlations between the three trends. Since most units of the data (publication, subscription, and citation) took place within the same circle of Japanese geography, it can be inferred that the correlations are not accidental.

In Japan, there were 709 universities in 2004 (Ministry of Education, Culture, Sports, Science, and Technology 2004) and 246 of them had geography departments and/ or professors (Nippon chiri gakkai 2003). ${ }^{7}$ According to the database of the NACSIS Webcat and our inquiry into individual institutions, there were 33 university libraries possessing and/or subscribing to $P G,{ }^{8}$ which was only $4.6 \%$ of the Japanese universities and $13.4 \%$ of those with geography departments. It is clear that the journal was not widely subscribed to even in the circle of Japanese geography.

A comparison to other English geographical journals subscribed to in Japan would help better understand the status of $P G$. Using the NACISS Webcat and the results of Gutiérres and López-Nieva (2001), we attempted to locate $P G$ among the 'international' journals published in Anglophone countries and examined the nature of Japanese (universities') subscription to those journals. Table 1 shows the ranking of 'popular' geographical journals among Japanese universities. The position of $P G$ is the second lowest of the geographical journals considered 'international' by Gutiérres and López-Nieva (2001).

Unlike Economic Geography, Geographical Review, or Annals of the $A A G$ that was subscribed to by most of the universities with geography departments or professors in Japan, the subscription to $P G$ seems to be quite limited. However, this does not necessarily mean that $P G$ as a journal of political geography is unpopular. Japanese subscription to Anglo-American geographical journals has a peculiar bias.

Gutiérres and López-Nieva (2001) devise three kinds of "internationalization indicators" (IND's 1, 2, and 3) for the 'international' journals. We employed IND2 as an internationalization indicator for our analysis. ${ }^{9}$ The correlation coefficient between the journal possession and IND2 is -0.515 , suggesting a significant inverse relationship. What Table 1 tells us is that Japanese universities tend to subscribe to the English geographical journals that are less internationalized or are rather purely Anglo-American. This is not only because newly

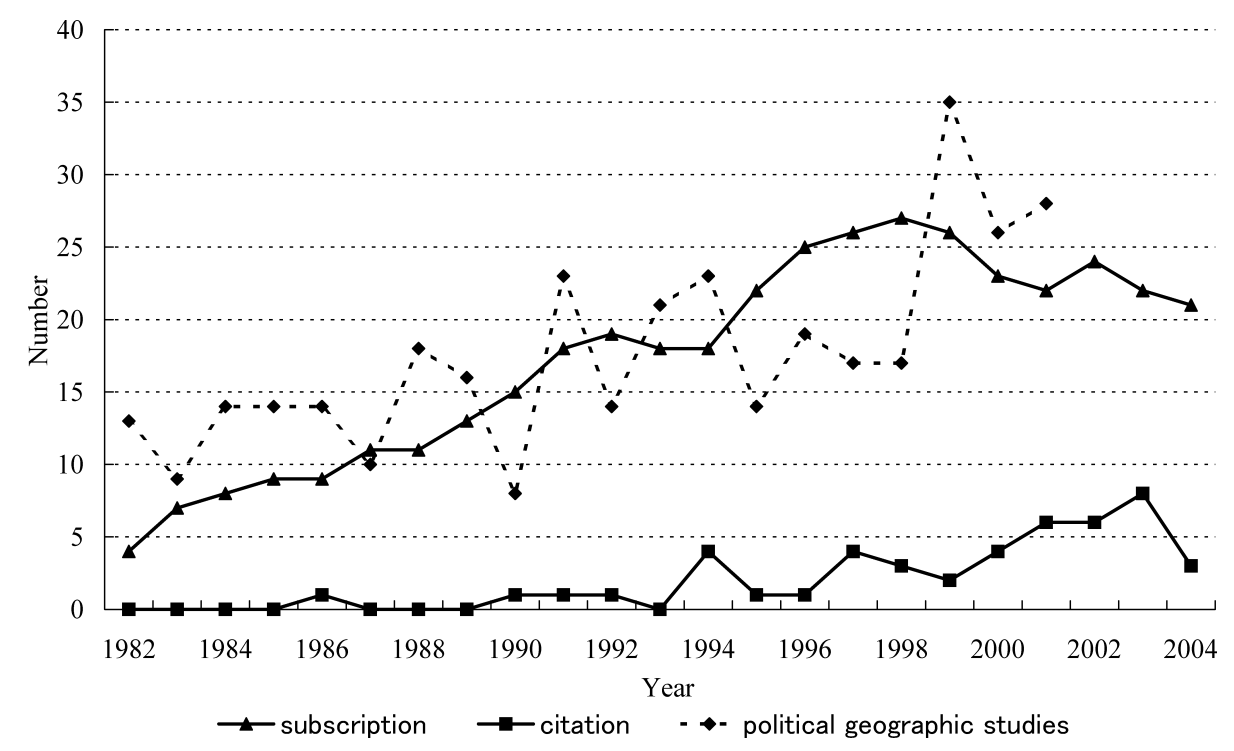

Figure 1. Subscription to and citation of Political Geography, 1982-2004 
Table 1. Possession of 'international' geographical journals by Japanese institutions, 2004

\begin{tabular}{|c|c|c|c|}
\hline 'International'journal & $\begin{array}{l}\text { Number of institutions } \\
\text { possessing the journal }\end{array}$ & $\begin{array}{l}\text { Internationalization } \\
\text { indicator (IND2)* }\end{array}$ & $\begin{array}{l}\text { Number of citations in } \\
46 \text { papers citing } P G^{* *} \\
(N=615)\end{array}$ \\
\hline Economic Geography & 286 & 0.14 & 26 \\
\hline Geographical Review & 259 & 0.07 & 12 \\
\hline Annals of the $A A G$ & 235 & 0.05 & 86 \\
\hline Geographical Journal & 207 & 0.32 & 0 \\
\hline Environment and Planning A & 156 & 0.36 & 56 \\
\hline Progress in Human Geography & 125 & 0.18 & 93 \\
\hline Professional Geographer & 117 & 0.08 & 15 \\
\hline Environment and Planning D & 108 & 0.31 & 60 \\
\hline Transactions, IBG & 105 & 0.07 & 44 \\
\hline Journal of Historical Geography & 92 & 0.37 & 21 \\
\hline Geographical Analysis & 85 & 0.29 & 2 \\
\hline Geography & 69 & 0.23 & 6 \\
\hline Urban Geography & 66 & 0.13 & 18 \\
\hline Area & 60 & 0.10 & 26 \\
\hline Geoforum & 53 & 0.48 & 17 \\
\hline Antipode & 52 & 0.40 & 12 \\
\hline International Journal of GIS & 46 & 0.65 & 13 \\
\hline Political Geography & 33 & 0.50 & 106 \\
\hline Applied Geography & 24 & 0.30 & 2 \\
\hline
\end{tabular}

Notes: * IND2 is employed from Gutiérres and López-Nieva (2001: 59). ** See the text.

Sources: The NACSIS Webcat (NII 2005) and Gutiérres and López-Nieva (2001).

founded commercial journals with higher IND2's tend to be unknown to Japanese geographers but also because postwar Japanese geographers have continued to pay attention to the development of Anglo-American geography. ${ }^{10}$ Absorbing or referring to the achievement of Anglo-American geography has been one of the major tasks for Japanese geographers. In this sense, the status or popularity of the journals to which relatively many nonAnglophone geographers contribute is not necessarily high in Japan. We argue that this reflects the academic power relations through English between Japan and Anglophone countries (for a similar argument, see Short et al. 2001; Minca 2003).

In terms of the number of students and type of each institution, most subscribing institutions are large urban universities. 21 out of the 33 institutions are more than twice as large as the national average (3,962 grad and undergrad students). The ten largest institutions are well-known private universities in the Kanto region including Tokyo, followed by well-known national and public universities. It can be said from this that $P G$ was subscribed to or possessed by larger-size universities with significant financial backgrounds although the proportion of such universities is quite small in Japan. The universities subscribing to or possessing $P G$ are concentrated in the metropolitan areas including Tokyo and Osaka. This indicates that the institutional location of $P G$ is highly centralized in the hierarchy of Japanese universities.

According to the information we gathered directly from those institutions, the subscription to $P G$ continued to increase until 1998 (Figure 1). We cannot necessarily specify why the journal's subscription grew at such a pace since the university librarians we contacted did not place the initial order for the subscription. However, from interviews with some Japanese geography professors, we presume that the foundation of $P G$ in 1982 gradually became known to Japanese geographers and that this led to an increase in subscription.

In terms of unsubscribing to $P G$, we received two kinds of answers. One is the recent introduction of the electric journal into Japanese universities. Elsevier as the publisher of $P G$ is actively promoting its online journal subscription in Japan. It can be predicted that the subscription to the printed copy of $P G$ will decrease in the future. ${ }^{11}$ The other is that geography departments 
or professors decided to suspend subscription for reasons such as the professors' retirement or transfer. We also assume that Japanese universities tend to unsubscribe to the journals that are not thought to be useful when they face university budget cuts or restructuring as seen after the late 1990s. Given its limited subscription, PG could become one of such unsubscribed journals in Japan. The recent decrease in subscription to its printed copy has been caused by these two changes.

The increase in subscription to $P G$ can be explained from a different point of view. Yamazaki (1997, 2001b) has pointed out that political geographic study in Japanese human geography began to increase in the late 1980s. As mentioned in the Introduction, the 'political turn' as a context of the time may have contributed to the increase of subscription. As shown in Figure 1, the increase of political geographic studies in Japan is in parallel with that of subscription. From this, we can infer that an increase in interest in $P G$ took place in the context of the 'political turn' in Japanese human geography.

\section{Citations of the Journal and Its Role}

In addition to the survey for subscription to $P G$, we conducted a citation analysis of the above-mentioned five Japanese geographical journals. As Table 2 shows, the number of citations in these journals from 1982-2004 is 46, most of which appear in two journals: Japanese Journal of Human Geography and Geographical Review of Japan. These two journals have nation-wide subscription and large memberships compared to the other journals. In this sense, although the citation of $P G$ is limited in number, it is not necessarily marginal in Japanese human geography as seen in its subscription.
Table 2. Citation of Political Geography by Japanese geographical journals, 1982-2004

\begin{tabular}{|c|c|c|}
\hline Journal & $\begin{array}{l}\text { Approximate } \\
\text { number of } \\
\text { membership } \\
\text { (as of 2004) }\end{array}$ & $\begin{array}{c}\text { Number of } \\
\text { articles citing } \\
P G\end{array}$ \\
\hline $\begin{array}{l}\text { Japanese Journal of Human } \\
\text { Geography }\end{array}$ & 1600 & 22 \\
\hline Geographical Review of Japan & 3000 & 14 \\
\hline Geography Sciences & 600 & 5 \\
\hline $\begin{array}{l}\text { Annals of the Japan Association of } \\
\text { Economic Geography }\end{array}$ & 800 & 4 \\
\hline Quarterly Journal of Geography & 900 & 1 \\
\hline Total & & 46 \\
\hline
\end{tabular}

Figure 1 also illustrates the relationships between subscription, research trends, and citation. The citation of $P G$ increases from the early 1990s on and the pattern of increase appears to follow the other two trends. It is reasonable to assume that the increase in subscription led to that of citation. As mentioned above, behind these trends, there was the general increase of political geographic studies in Japan. It can be inferred from this that the 'political turn' in Japanese human geography accompanied an increase in subscription to $P G$ that later led to an increase in citation.

A closer look at the citation of the journal reveals more findings. The first citation appeared in 1986 four years after the journal was founded. Since then $P G$ has been cited 106 times. Table 3 gives us summarized information about the (co-)authors and their articles citing PG. From 1982-2004, 48 authors cited $P G$ in their 46 refereed articles including three English articles. While many of

Table 3. Citation data profile

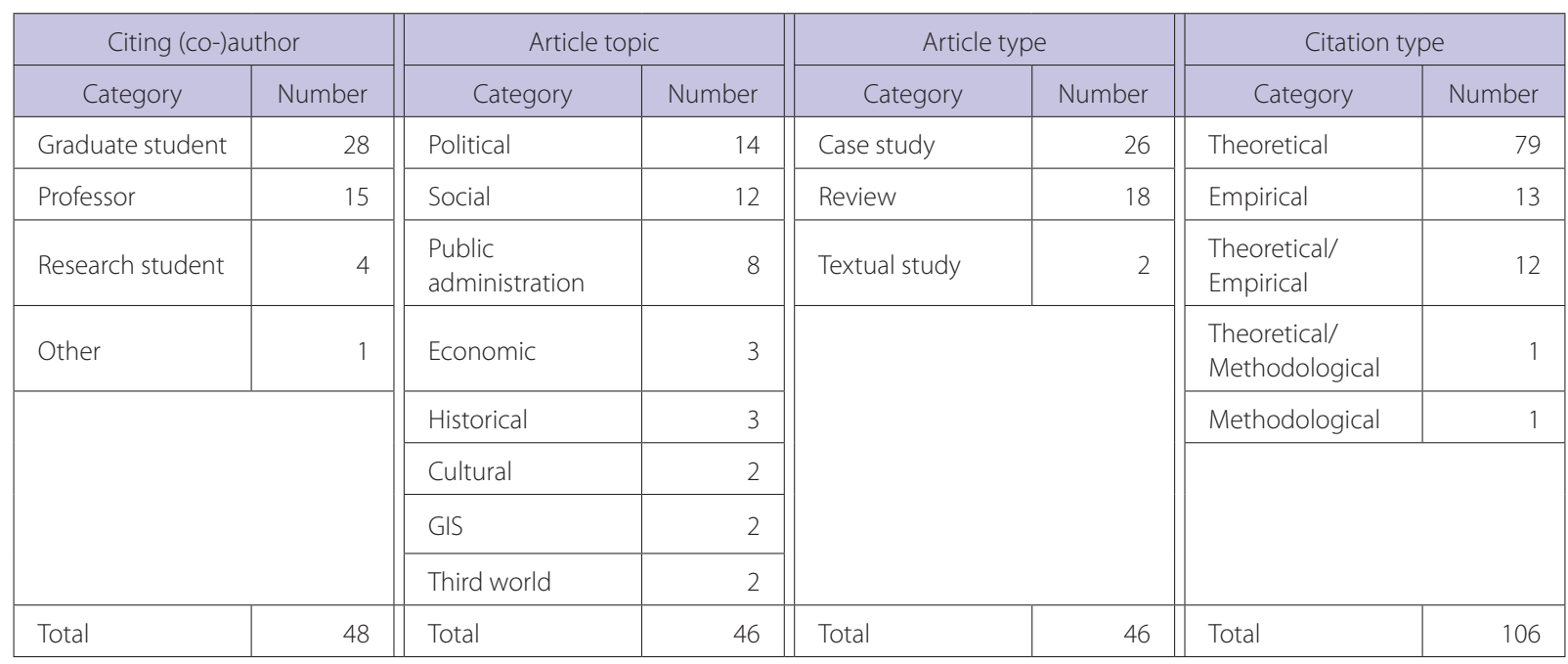


these articles cite only one article in $P G$, some (review) articles cite many articles in the journal (e.g. Takagi 1991, Yamazaki 2001a, 2001b). Although some articles cite $P G$ much less frequent than journals such as Annals of the AAG, Progress in Human Geography, and Environment and Planning $D, P G$ generally holds the status of one of the major sources of citation (see Table 1).

78 articles in $P G$ were cited in Japan. Liz Bondi’s article on school closures (Bondi 1987) is most frequently cited ( 6 times) and is followed by Takashi Yamazaki's on Japanese political geography (Yamazaki 1997, 4 times). However, these articles were cited twice by the same author(s) or the author himself. In addition, since Yamazaki's review articles (Yamazaki 2001a, 2001b) cite many articles in $P G$, these articles would not have been cited more than once without his articles. It is thus difficult to say that any single article in $P G$ has a significant impact on Japanese human geography.

However, an analysis of $P G$ 's articles by author gives a different and truer picture. The number of the citation of John Agnew's articles (14 times) is outstanding. The works by Peter Taylor ( 6 times), Paul Routledge ( 5 times), and Joanne Sharp (5 times) have also been repeatedly cited. Takagi (1991) introduces Agnew (1982) as a critique of the deterministic aspects of Wallerstein's world systems theory but also mentions that Agnew later published a textbook based on that theory. Izumitani (1998) refers to Agnew (1996) as a work emphasizing the ontological meaning of contextual effect in election. Izumitani (1998) as well as Yamazaki (2001b) explain theoretical implications of the debates over contextual effect between political geographers and political sociologists/scientists. As Yamazaki (2001b) shows, Ó Tuathail and Agnew (1992) have also been introduced to Japanese geography as one of the essential readings on critical geopolitics. Japanese geographers are now becoming familiar with Agnew's works on election and geopolitics.

Since Takagi (1991) reviewed Taylor's introduction of world-systems theory into political geography and translated his well-known textbook in the early 1990s (Taylor 1989), Taylor's works on the agendas of political geography (Taylor 1982a, 1982b), the global development of world cities (Taylor 2000b), and the problematic aspects of GIS (Taylor 1990) have appeared in Japanese geographical journals. Although the number of Taylor's article in $P G$ has been limited due to his position as the journal's former editor, his theoretical contribution to political geography is recognized by Japanese geographers as well.

As Japanese interests in Anglo-American political geography grow, more attention is being paid to works by younger political geographers such as Routledge and Sharp. In his works on social movements, Kagawa (2003, 2004) cites Routledge $(1992,1996)$ and Miller $(1994,1997)$ as important theoretical and empirical contributions to geographical studies on social movements. Extensively referring to Sharp (1993), Naruse $(1994,1997)$ explores approaches of popular geopolitics to investigate how the world order is constructed in the public mind. As shown above, articles by Agnew and his students such as Ó Tuathail, Routledge, and Sharp have often been cited in Japan, reflecting the influence of postmodern geographies developed in Anglophone countries.

In other fields of political geography, Sugiura (1997, 1998) draws on Boyne and Powell (1991), which is a theoretical and methodological examination of territorial justice, for his normative approach to the welfare of the elderly in Japan. In his pioneering studies on the geography of Japanese youth, Sugiyama $(2002,2003)$ refers to Fyfe's works on the legal control of public space and youth in the United Kingdom (Fyfe 1995). Murata (2002) criticizes Yamazaki (2001b) for the lack of attention to studies on sexual politics such as Bell (1995). It seems that Japanese geographers have obtained theoretical and methodological insights from articles in $P G$.

Other important aspects in the citation of $P G$ are also shown in Table 3. First, two-thirds of the authors citing $P G$ are graduate or post-doctoral students and the average age at which the authors published those articles is 31.6. This indicates that $P G$ is read and cited by fairly young Japanese geographers ${ }^{12}$ while the older generation (fulltime professors) decided to subscribe to the journal at their universities. This implies that $P G$ has been regarded as a journal for a new trend and generation in Japanese human geography. The fact that younger geographers tend to cite articles in $P G$ may also imply the continuation of the journal's readership in Japan.

Second, we classified the articles citing $P G$ by three criteria: article topic, article type, and citation type. The topics of the cited articles were classified into eight categories. Approximately $30 \%$ of the articles were coded as "political," meaning that they are on political geography in general, election, state, geopolitics, etc. The articles on social issues such as education, gender, or social institutions constitute $26 \%$ and were coded as "social." Those on public administration such as public service provision or finance follow these two categories. Therefore, the topics of the articles citing $P G$ are so diverse that $P G$ is cited in a variety of sub-disciplines of Japanese human geography. 
Third, in terms of article type, the largest category is "case study," meaning that Japanese geographers tend to cite $P G$ for their empirical studies. The fact that 18 review articles cite $P G$ reflects that articles in well-known English journals tend to be considered 'good' references in Japanese academia.

Finally, the analysis of citation type reveals problematic practices of Japanese geographers. Citation type shows in what context of analysis or argument articles in $P G$ were cited. "Theoretical" means that articles in Japan refer to articles in $P G$ as giving theoretical, conceptual, and/or philosophical insights. "Empirical" on the other hand represents the Japanese articles that list articles in $P G$ as examples of case study. "Methodological" denotes reference to analytical methods employed in $P G$ 's articles. Since it was not always easy for us to code each article with a single category, 13 articles were coded with two of these categories. ${ }^{13}$ However, approximately $75 \%$ of the articles citing $P G$ fall into "theoretical," indicating that the journal has been used mostly for the application of or the argument about theoretical perspectives in AngloAmerican political geography. Out of 29 citations in 26 case study articles in Japan, five (17.2\%) are 'purely' empirical, so are $8(16 \%)$ out of 50 citations in 18 review articles. More than $80 \%$ of the case studies in Japan cite $P G$ for theoretical reference. Here we find the clear academic trade imbalance between the production and the consumption of theory in political geography.

Among the case studies cited by Japanese geographers are Knopp's work on gentrification in a gay community in New Orleans (Knopp 1990 cited by Fujitsuka 1994), Livingstone's and others' religious geographic study on Belfast (Livingstone et al. 1999 cited by Mori 2002), Shelley's argument about the intergovernmental relations regarding educational financial resources in the United States (Shelley 1994 cited by Tsutsui 2002), and Giordano's study on the politics of scale by the Northern League in Italy (Giordano 2000 cited by Kitagawa 2004). Although articles in $P G$ have provided reliable sources of empirical reference for Japanese geographers, some of the empirical citations seem arbitrary and do not necessarily cite works representing each research field. As shown above, one of the common aspects in Japanese citation is that particular Japanese authors have cited particular authors' articles in $P G$ for their theoretical, methodological, and empirical frameworks. This again indicates that citation by individual Japanese authors tends to be arbitrary rather than selective based on the extensive review of each research field. This may be because it is easier for Japanese geographers to refer to generalized, therefore theoretical, aspects of articles in $P G$ than to assess the values of various case studies in a foreign language.

Moreover, given that there have been only two Japanese (i.e. Japanese-university-affiliated authors') contributions to $P G$ (Yamazaki 1997; Fukushima 1997) and that $P G$ still retains a strong Anglo-American bias (Waterman 1998), the relationship between the citing world and the cited world remains remarkably unilateral (see Minca 2003). We argue that the case of $P G$ at least partially illustrates how Japanese geographers have been influenced by the theoretical development of Anglo-American political geography in particular and human geography in general.

\section{Conclusion}

We have thus far drawn a rough sketch of the subscription to and citation of $P G$ in Japan. In the general context of the increase of political geographical studies for the past decades, the institutional subscription to $P G$ had been increasing in number until the end of 1990s. Given that these trends took place within the same circle of Japanese human geography, we argue that the 'political turn' included a trend of enhancing the status of $P G$ in Japan. We believe that $P G$ has already been regarded as an 'international' journal representing the sub-discipline among Japanese geographers. It can be said therefore that for younger geographers, $P G$ has been recognized as one of the major reference sources for political geographic studies. Although the quantity of the journal's readership seems much smaller than other 'international' English Journals, the journal's status in the hierarchy of Japanese universities and geographic journals is not necessarily marginal. The results of our analyses in this paper well illustrate how $P G$ has established its status and been accepted in Japan.

The citation analysis of $P G$ has revealed several important aspects of the usage of the journal in Japan. Although any single article in $P G$ does not seem to significantly influence Japanese geographers, articles by particular authors such as Agnew and his students in $P G$ were frequently cited, meaning that $P G$ plays a role as one of the gates for such studies in Japan. If leading political geographers in Anglophone countries continue to publish their articles in $P G$ the journal's status in Japan will be maintained.

On the other hand, we argue that such a tendency of citation can be problematic. While Japanese geographers predominantly cite $P G$ for theoretical reference in their case studies, few of them have contributed their works to $P G$. This is one of the postwar common practices among 
Japanese geographers. In this uneven relationship, the academic trade imbalance between the cited world and the citing world has been reproduced. Unfortunately, $P G$ has so far been used as a pipe channeling Euro-American theories into Japanese geography. While Japanese geographers can be influenced by the journal, the opposite would never be the case in such a relationship.

Even though we have employed IND2 as an indicator to show $P G$ 's 'internationality', we do not think that the journal is truly international, or fully open to the world. Without any academic and educational background in Anglophone countries, it would be very difficult to communicate with the journal more than simply reading and citing it. Due to such language and cultural barriers, the journal has not yet been internationalized for the non-Anglophone countries such as Japan (see also Minca 2003). These barriers have also been reinforced by the use of English as a nominally 'global' language (Short et al. 2001). Although the increase of Japanese geographers' interest in $P G$ during the past decades may become a chance to lower the barriers, there is a possibility that we just reproduce the academic trade imbalance.

What can be done to improve this uneven relationship? We propose some options to conclude this paper. In parallel with the increasing introduction of electronic journals into Japan, the download of $P G$ by Japanese scholars seems to be constantly increasing. ${ }^{14}$ According to John O'Loughlin, the editor of the journal since its foundation, the introduction of the online submission system into the journal has led to the further internationalization of contributors. ${ }^{15}$ At the international level, the expansion of subscription to the journal through the Internet seems to be related to that of submission (and the number of articles in each issue of the journal). In order to counteract the academic trade imbalance and promote international academic exchange, non-Anglophone contributors may need to improve their English communication and publication skills. The Japanese government and universities have already initiated policies to promote such a process. ${ }^{16}$ However, this is in itself part of uneven linguistic power relations in the world. An option to avoid reproducing such uneven power relations would be to promote joint research and co-authorship for publication between Anglophone and non-Anglophone geographers through such opportunities as international conferences. This type of partnership would effectively bridge the gap between the cited and citing worlds.

The editors of $P G$, on the other hand, may be able to publish a series of papers to introduce the diversity of political geographies in the world to its readers. They could also encourage the submission of the translations of non-English papers influential in non-Anglophone countries. Given that $P G$ s editorial board members are quite diverse and international, these are feasible options to make the journal more international and attractive to the world. Exercising those options, $P G$ would surely stimulate academic interest in political geography in a more global context and be able to de-Anglo-Americanize the sub-discipline in its nature.

\section{Acknowledgments}

We would like to thank John O'Loughlin and Tony Roche for their kind replies to our inquiries; and the Japanese university librarians and geography professors we contacted for their generous cooperation with our survey.

\section{Notes}

1. This paper was originally written for the Association of American Geographers Political Geography Specialty Group Preconference "Political Geography: Retrospect and Prospect" held in Boulder, Colorado, USA from April 3-5, 2005. The summarized version of this paper will also be published as "Editorial" for the journal Political Geography.

2. From the late 1980s to the early 1990s there was a drastic increase in political studies in Japanese human geography due mainly to an increase in articles on international affairs published in the journal Geography (Chiri) (Yamazaki 1997). This reflected the end of the Cold War and related political restructuring in the world. With regards to the status of the nation-state in an era of globalization and the review of related political geographic studies, see Yamazaki (2001a).

3. One of the most active contributors to such introduction is the annual journal Space, Society and Geographical Thought (Kukan, shakai, chirishiso) published by Osaka City University since 1996.

4. We use 'political turn' rather than 'cultural turn' that means a broader perspective shift in cultural studies because we pay attention to increasing interest in the political as a derivative of 'cultural turn.'

5. However, the category "politics" was broadly defined and included studies in fields other than geography.

6. We confined the scope of our analysis to journal articles mainly because intermittently published books did not necessarily reflect a continuous trend. Only four books with the term seiji chiri (political geography) in their titles were newly published in Japan from 1982-2004. Two of them were translations including Taylor (1989).

7. There were 756 universities and 248 of them had geography departments and/or professors in 2007 (Monbu kagaku sho 2007, Nippon chiri gakkai 2007). 
8. In 2004, 33 university libraries 'possessed' copies of the journal, and 21 of them were still 'subscribing' to it, meaning that 12 libraries stocked but unsubscribed to the journal.

9. According to Gutiérres and López-Nieva (2001) the three indicators represent the following:

IND1: proportion of contributions from different countries to the country which contributes most articles,

IND2: contributions from the non-Anglo-Saxon world divided by those from the country which makes most contributions, and

IND3: inverse of the standard deviation of the proportion of contributions of the different countries multiplicated by 100 .

In light of the objective of this paper, we selected IND2 as the most appropriate index.

10. Before the Second World War, German and French geographies were more influential in Japan.

11. According to Kokuritsu kokkai toshokan (2004: 18-24), Japanese (mainly national and other large-scale) universities have introduced electronic journals, and more than $60 \%$ of them are subscribing to ScienceDirect ${ }^{\circledR}$. Tony Roche, then Senior Publishing Editor for Geography and Planning of Elsevier $^{\circledast}$, also suggested to one of us (Yamazaki) in his email of June 2005 that the usage of $P G$ continued to migrate to the journal on ScienceDirect ${ }^{\circledR}$.

12. According to Yagasaki (2005: I) and Amano (2004: 17), the average ages of the authors for Annals of the AAG (19842003), Geographical Review of Japan (1984-2003), and The Historical Geography (Rekishi chirigaku, 1959-2004) are 42.6, 37.9 , and 46.0 , respectively.

13. In order to determine the type of each citation, we first specified the lines citing an article (articles) in $P G$ in a Japanese article, and each of us tentatively coded its citation type(s). When we had different results, we discussed if we could reach single coding. Otherwise, we employed double coding for the citation.

14. Although we cannot disclose the exact sales information Tony Roche gave us, the download of the journal by Japanese institutions has been increasing in number for the past several years. The number of the worldwide downloads of articles in the journal became $400 \%$ larger in 2004 than in 2000.

15. One of us (Yamazaki) interviewed O'Loughlin at his office on March 31, 2005.

16. Since the beginning of this century many Japanese universities have begun state-subsidized "Center of Excellence" or "Good Practice" projects in which students can improve their English communication and publication skills in order to transmit information about Japan.

\section{References}

Agnew, J. A. 1982. Sociologizing the geographical imagination: Spatial concepts in the world-system perspective. Political Geography Quarterly 1: 159-166.

Agnew, J. A. 1996. Mapping politics: How context counts in electoral geography. Political Geography 15: 129-146.
Amano, K. 2004. The paper productive age in the Association of Historical Geographers in Japan: It respond(sic) to the Yagasaki report in the Association of Japanese Geographers Autumn Convention in 2004. Rekishi chirigaku (The Historical Geography) 46(5): 15-24. (JE)

Bell, D. 1995. Pleasure and danger: The paradoxical spaces of sexual citizenship. Political Geography 14: 139-153.

Bondi, L. 1987. School closures and local politics: The negotiation of primary school rationalization in Manchester. Political Geography Quarterly 6: 203-224.

Boyne, G. A. and Powell, M. A. 1991. Territorial justice: A review of theory and evidence. Political Geography Quarterly 10: 263281.

Elsevier 2005. Flyer distributed at the 2005 Association of American Geographers annual meeting in Denver. Elsevier.

Fujitsuka, Y. 1994. Gentrification: A review of research in western countries and future research on Japanese cities. Japanese Journal of Human Geography 46: 496-514 (JE).

Fukushima, Y. 1997. Japanese geopolitics and its background: What is the real legacy of the past? Political Geography 16: 407-421.

Fyfe, N. R. 1995. Law and order policy and the spaces of citizenship in contemporary Britain. Political Geography 14: 177-189.

Giordano, B. 2000. Italian regionalism or 'Padanian' nationalism? The political project of the Lega Nord in Italian politics. Political Geography 19: 445-471.

Gutiérres, J. and López-Nieva, P. 2001. Are international journals of human geography really international? Progress in Human Geography 25: 53-69.

Izumitani, Y. 1998. Relationship of abstention rate between national and local election: A casual analysis from contextual point of view. Japanese Journal of Human Geography 50: 507-521. (JE)

Jinbun chiri gakkai bunken mokuroku henshu iinkai. 1989. Chirigaku bunken mokuroku dai 8 kan (Geographical Bibliography Vol. 8). Tokyo: Taimeido. (J)

Jinbun chiri gakkai bunken mokuroku henshu iinkai. 2004. Chirigaku bunken mokuroku dai 11 kan (Geographical Bibliography Vol. 11). Tokyo: Kokon-shoin. (J)

Kagawa, Y. 2003. The locality of the anti-pollution movement in Wakayama. Japanese Journal of Human Geography 55: 43-57. (JE)

Kagawa, Y. 2004. Geography on the theory of social movements and its development in geography. Geographical Sciences 59: 26-46. (JE)

Kitagawa, S. 2004. Place and new right politics: Discursive practice on "Padania" of the Lega Nord in Italy. Japanese Journal of Human Geography 56: 134-153. (JE)

Knopp, L. 1990. Some theoretical implications of gay involvement in an urban land market. Political Geography Quarterly 9: 337352.

Kokuritsu kokkai toshokan. 2004. Denshi joho kankyoka niokeru kagakugijutsu joho no chikuseki ryutsu no arikata ni kansuru chosa kenkyu (Research report on the way of accumulation and circulation of scientific and technological information under the circumstances of electronic information). Toshokan chosa kenkyu ripoto No. 2. http://www.ndl.go.jp/jp/library/lis_ research/lis_rr_02.pdf (last accessed August 2005). (J)

Livingstone, D., Keane, M. and Boal, F. 1999. Space for religion: A 
Belfast case study. Political Geography 17: 145-170.

Miller, B. 1994. Political empowerment, local-central state relations, and geographically shifting political opportunity structures: Strategies of the Cambridge, Massachusetts, Peace Movement. Political Geography 13: 393-406.

Miller, B. 1997. Political action and the geography of defense investment: Geographical scale and the representation of the Massachusetts Miracle. Political Geography 16: 171-185.

Minca, C. 2003. Critical peripheries. Environment and Planning D: Society and Space 21: 160-168.

Ministry of Education, Culture, Sports, Science, and Technology. 2004. Statistical Abstract 2004 edition. http://www.mext.go.jp/ english/statist/index.htm (last accessed March 2005).

Mizuoka, F. 1974. The revival of "geopolitics" in contemporary geography. Economics (Keizai) 119: 175-196. (JE)

Monbu kagaku sho (Ministry of Education, Culture, Sports, Science, and Technology) 2007. Heisei 19 nendo gakko kihon chosa (Statistical Abstract 2007 edition). http://www.mext. go.jp/b_menu/toukei/001/08010901/004/001.xls (last accessed June 2009). (J)

Mori, M. 2002. Spatial formation and change in the Henro pilgrimage in modern Japan. Japanese Journal of Human Geography 54: 535-556. (JE)

Murata, Y. 2002. The politics of space involving male heterosexuality: The case of a Japanese politician's statement in 1999. Japanese Journal of Human Geography 54: 557-575. (JE)

Naruse, A. 1994. Towards Cultural Studies in Geography in Japan. Geographical Sciences 49: 95-108. (JE)

Naruse, A. 1997. Geopolitical awareness and criticism. Geographical Review of Japan 70A: 156-166. (JE)

Nippon chiri gakkai. 2003. Nippon chiri gakkai kaiin meibo (the Members' Directory of the Association of Japanese Geographers). Tokyo: Nippon chiri gakkai. (J)

Nippon chiri gakkai. 2007. Nippon chiri gakkai kaiin meibo (the Members' Directory of the Association of Japanese Geographers). Tokyo: Nippon chiri gakkai. (J)

NII. 2005. The NACSIS Webcat. http://webcat.nii.ac.jp/ (last accessed March 2005).

Ó Tuathail, G. and Agnew, J. 1992. Geopolitics and discourse: Practical geopolitical reasoning in American foreign policy. Political Geography 11: 190-204. Translated by M. Morisaki and A. Takagi 1998. Kukan, shakai, chirishiso (Space, Society and Geographical Thought) 3: 155-168. (J)

Powell, J. M. 1999. Environment, culture and modern Historical Geography: Recent Anglophone contributions. Japanese Journal of Human Geography 51: 477-493.

Routledge, P. 1992. Putting politics in its place: Baliapal, India, as a terrain of resistance. Political Geography 11: 588-611.

Routledge, P. 1996. Critical geopolitics and terrains of resistance. Political Geography 15: 509-531.

Sakamoto, H. and Hamatani, M. 1985. Saikin no chirigaku (The Recent Geography). Tokyo: Taimeido. (J)

Sharp, J. P. 1993. Publishing American identity: Popular geopolitics, myth and The Reader's Digest. Political Geography 12: 491503.

Shelley, F. M. 1994. Local control and financing of education: A perspective from the American state judiciary. Political
Geography 13: 361-376.

Short, J. R., Boniche, A., Kim, Y. and Li, P. L. 2001. Cultural globalization, global English, and geography journals. Professional Geographer 53: 1-11.

Smith, N. 2000. The restructuring of spatial scale and the new global geography of uneven development. Japanese Journal of Human Geography 52: 51-66.

Sugiura, S. 1997. Welfare services for the elderly and territorial justice in Hiroshima prefecture, Japan. Geographical Review of Japan 70A: 418-432. (JE)

Sugiura, S. 1998. Welfare services for the elderly in a metropolitan municipality: Provision and use of nursing homes in Nagoya city. Japanese Journal of Human Geography 50: 128-149. (JE)

Sugiyama, K. 2002. The relationship between coverage in local newspapers and the organization of purification acts: The movement of 'harmful' environments for juveniles problems in Toyama prefecture. Geographical Sciences 57: 73-89. (JE)

Sugiyama, K. 2003. Geographies of youth: Research issues concerning the "Cultural Turn" of Anglophone human geography. Japanese Journal of Human Geography 55: 26-42. (JE)

Takagi, A. 1991. The world-system analysis and new trends in Political Geography. Geographical Review of Japan 64A: 839858. (JE)

Takeuchi, K. 1974. Geoplitik in Japan. Hitotsubashi ronso 72: 169191. (JE)

Takeuchi, K. 1986. The revival of Geopolitik and the new development of political geography: A re-reexamination of Geopolitik. Hitotsubashi ronso 96: 524-546. (JE)

Taylor, P. J. 1982a. Political geography-research agendas for the nineteen eighties. Political Geography Quarterly 1: 1-17.

Taylor, P. J. 1982b. Research agendas for the nineteen eighties: Comments, additions and critiques. Political Geography Quarterly 1: 167-180.

Taylor, P. J. 1989. Political Geography: World-Economy, Nation-State, and Locality Vols. 1 and 2. London: Longman Scientific \& Technical. Translated by A. Takagi 1991, 1992. Sekai shisutemu no seiji chiri: Sekai keizai, kokumin kokka, chiho jo, ge. Tokyo: Taimeido. (J)

Taylor, P. J. 1990. GKS. Political Geography Quarterly 9: 211-212. Translated by A. Ikeguchi 2002. Kukan, shakai, chirishiso (Space, Society and Geographical Thought) 7: 38-39. (J)

Taylor, P. J. 2000a. Political geography. In The Dictionary of Human Geography, ed. R. J. Johnston, D. Gregory, G. Pratt and M. Watts, 594-597. Oxford: Blackwell.

Taylor, P. J. 2000b. World cities and territorial states under conditions of contemporary globalization. Political Geography 19: 5-32.

Tsutsui, K. 2002. A geographical analysis of the public finance of compulsory education in peripheral Japan. Annals of the Japan Association of Economic Geography 48: 1-22. (JE)

Waterman, S. 1998. Political Geography as a mirror of political geography. Political Geography 17: 373-388.

Yagasaki, N. 2005. Geographers' age of producing papers. Geographical Review of Japan 78: i-iii. (JE)

Yamazaki, T. 1995. What political and administrative geography should aim at? Geography (Chiri) 40: 69-73. (JE) 
Yamazaki, T. 1997. Political geography in post-war Japan: Publication tendencies. Political Geography 16: 325-344.

Yamazaki, T. 2001a. The nation-state and nationalism in an era of globalization: A review of Anglophone research trends. Geographical Review of Japan 74A: 512-533. (JE)
Yamazaki, T. 2001b. Issues in Anglophone political geography. Japanese Journal of Human Geography 53: 532-555. (JE)

(J): written in Japanese

(JE): written in Japanese with English abstract 